\title{
Case Study of Biodiesel-Diesel Blends as a Fuel in Marine Environment
}

\author{
Tianxi Zhang ${ }^{1}$, Yapeng Chao ${ }^{1}$, Nan Liu ${ }^{1}$, Joe Thompson ${ }^{2}$, Manuel Garcia ${ }^{1}$, \\ Brian B. $\mathrm{He}^{2}$, Jon Van Gerpen ${ }^{2}$, Shulin Chen ${ }^{{ }^{*}}$ \\ ${ }^{1}$ Department of Biological Systems Engineering, Washington State University, Pullman, USA \\ ${ }^{2}$ Department of Biological and Agricultural Engineering, University of Idaho, Moscow, USA \\ E-mail:chens@wsu.edu \\ Received February 16, 2011; revised March 24, 2011; accepted March 29, 2011
}

\begin{abstract}
Formation of excessive sludge and fuel filter clogging were experienced in using biodiesel blends under marine environment. In this study, a field test was conducted in a marine ferry boat fueled by canola-based biodiesel blends. The sludge materials collected in the fuel purifier were characterized using inductively coupled plasma (ICP), pyrolysis-GC/MS (Py-GC/MS), thermogravimetric analysis (TGA), and Karl-Fischer titration. It was found that the sludge materials consisted of four distinctive fractions: organic materials derived from diesel and canola biodiesel (major fraction), ash $(11 \%-14 \% \mathrm{w} / \mathrm{w})$, water $(\sim 17 \% \mathrm{w} / \mathrm{w})$, and bacteria. The active bacteria were present in the sludge samples. It was suggested that bacterial contamination was one of the major factors in contribution to the sludge formation.
\end{abstract}

Keywords: Biodiesel, Sludge, Filter Clogging, Microorganisms, Marine Environment

\section{Introduction}

Formation of insoluble material in biodiesel blends has drawn great attention as it causes clogging of filters [1]. One reason that blends-containing biodiesel is prone to formation of insoluble material is the relatively high temperature of crystallization (or solidification) compared to petro-diesel. When biodiesel is used at low temperatures, crystals tend to form and clog fuel filters. When temperatures are even lower, biodiesel exhibits jelly-like behavior and cannot be pumped. According to ASTM standard D6751, three parameters are used to evaluate biodiesel's cold flow properties: cloud point (CP), pour point (PP), and cold filter plugging point (CFPP). Biodiesel has relatively high values for $\mathrm{CP}$ and PP that limit its application as neat fuel (B100) under low temperature conditions [1]. Extensive research has been conducted on cold flow properties of biodiesel from various feedstocks. Dunn et al. summarized the cold flow properties of methyl and ethyl esters of biodiesel derived from several feedstocks and found that CP, PP, and CFPP of these biodiesels varied quite widely [2]. Fuel additives are typically used to improve the cold flow properties of petro-diesel under extremely low temperature conditions [2]. These additives usually contain copolymers of ethylene and vinyl acetate or other olefin-ester copolymers. In general, they act by distorting the wax crystal shape and size to inhibit crystal growth, thereby reducing PP temperatures. These additives seem to work similarly in biodiesel blends: one study demonstrated significant reduction of PP and CP for soy biodiesel and its blends with \#2 diesel, with ethyl ester additives proving more effective than methyl ester [3].

Another reason for development of insoluble material in biodiesel is that minor fuel components, such as sterol glucosides and monoglycerides, can form precipitates under certain conditions. These precipitates agglomerate over time into flocs and sediments. The sterol glucoside content in biodiesel may vary from supplier to supplier based on both the feedstock origins and the processing technologies used. The insoluble materials formed at low temperature have recently been characterized from several oil feedstocks, such as soybean, palm, yellow grease, and cottonseed $[4,5]$. The authors reported isolation of insoluble steryl glucosides from soybean-based oil, monoglycerides from palm oil, and steryl glucosides and monoglycerides from cottonseed oil.

Application of biodiesel blends in marine environment is prone to even greater sludge formation than standard land applications [6]. It has been generally believed that formation of insoluble material in marine conditions may occur by a new mechanism, outside of low temperature 
crystallization and precipitation of minor components.

This speculation was supported by the results from a pilot test conducted by the Washington State Ferries (WSF) in the Port of Seattle during a four month period in 2004. B20 (20 percent biodiesel) fuel blend was used in the test that resulted in the formation of excessive sludge material, which led to the clogging of filters [6]. Additional sludge materials were also found in the centrifugal fuel purifiers. These purifiers function to separate water and solid contaminants from fuel by differences in densities and centrifugal forces. The formation of excessive sludge material was not clear and sludge properties were not characterized in that pilot test.

Identifying the cause of fuel clogging in such a marine environment is not a trivial task, because biodiesel-diesel blends are not simply stored in a static and isolated environment on marine vessels. Biodiesel blends are transferred into one of the storage tanks in the vessel from tanker trucks, and the fuel is therefore subject to mixing in the storage tank. The fuel is then transferred from the storage tank into day tanks through centrifugal fuel purifiers, pumps, and filters. Finally, the fuel is pumped under pressure in service piping through filters, hoses, and engine fuel injection equipment, into the engine, with some fuel returning to the fuel oil day tanks. The environmental conditions under which biodiesel is used are therefore dependent not only on weather, but also on the processes used on each particular marine vessel.

In order to understand the causes of filter clogging and sludge properties, another pilot test was conducted during 2008-2009 as a part of study. Sludge formation was experienced again in this test. This study reports findings from examination and characterization of the sludge material obtained from that pilot test, including results obtained using pyrolysis-GC/MS (Py-GC/MS), thermogravimetric analysis (TGA), inductively coupled plasma (ICP), and Karl Fisher (K-F) titration, as well as presence of microbes and probable polysaccharides in the sludge materials.

\section{Materials and Methods}

\subsection{Pilot Test in the WSF System}

The Tillikum, a Washington State Ferry vessel, was fueled with canola-based biodiesel/diesel blends B5, B10, and B20 and operated for a period of one year (April 2008-April 2009). This was the same vessel that experienced excessive filter clogging problems during the pilot tests conducted in 2004 with soybean-based B20 biodiesel-diesel blends. The fuel tanks of this vessel were carefully cleaned before the first canola B5 blend was loaded. The objective of cleaning is to remove any tank sediment coating the tank walls as the tanks were origi- nal steel in over 50 years old. High pressure hot-water was used to get tanks cleaned. Initially, the fuel system appeared to be running well without excessive sludge buildup in the purifier. However, sludge accumulation within the fuel purifier was found in May 2008, about six weeks after starting the tests. Excessive sludge formation resulted in filter clogging. This sludge appeared to be very similar to the samples collected in the 2004 tests. In spite of twice-weekly cleaning to remove the sludge, sludge buildup in the purifier continued to be recurred.

In a control test, another vessel run regular $100 \%$ Ultra-Low Sulfur Diesel (ULSD). About 15,700 gallons of ULSD diesel were burned. No excessive sludge, however, was found during the test period.

\subsection{Materials}

Neat canola-based biodiesel (B100) which met current standard specification (ASTM D 6751-07) was obtained from Imperium Renewable Inc. (Seattle, Washington, USA), and ultra low sulfur diesel (ULSD) was purchased from the local market. Biodiesel blend fuels were prepared by blending the B100 and ULSD at certain volumetric ratios. Reported here are the properties of two sludge samples collected in the purifier which is between storage tank and day tank on May 27 $7^{\text {th }}, 2008$ (Sample \#1) and May $31^{\text {st }}, 2008$ (Sample \#2).

\subsection{Microbial Cultivation}

In order to identify microbial types in the sludge, microbial culture experiments were performed. Four types of solid media were used for the microbial growth. Plate count agar (PCA, Type 1) was designed for detecting bacteria, potato dextran agar (PDA, Type 2) was used for cultivating fungi that might be present in the sludge, malt extract agar (MEA, Type 3) was used mainly for cultivating potential yeasts in the sludge, and anaerobic agar (AA, Type 4) was designed for observing microbes that could grow under anaerobic conditions. Components of the media were summarized in Table $\mathbf{1}$ as below.

In addition, a small amount of the sludge was inoculated and incubated. The procedure of microbial culture

Table 1. Components of culture media.

\begin{tabular}{cl}
\hline Media & \multicolumn{1}{c}{ Components } \\
\hline Type 1 & $\begin{array}{l}\text { PCA with pancreatic digest of casein, yeast extract, } \\
\text { dextrose, and agar }\end{array}$ \\
Type 2 & PDA with potato starch, dextrose, and agar \\
Type 3 & $\begin{array}{l}\text { MEA with maltose, dextrose, glycerol, peptone, and agar } \\
\text { AA with agar with casein peptone, sodium chloride, } \\
\text { Type } 4\end{array}$ \\
& $\begin{array}{l}\text { dextrose, sodium thioglycollate, soy peptone, L-cystine, } \\
\text { agar, sodium sulfoxyl formaldehyde, and methylene blue }\end{array}$ \\
\hline
\end{tabular}


was described elsewhere [7]. To be briefly, $0.10 \mathrm{~g}$ of wet sludge was weighed under sterile conditions, suspended in $1.0 \mathrm{ml}$ of sterile deionized water, and vortexed for ten minutes. The suspended samples were diluted by a factor of 5000 and then the resultant samples were spread on the culture plates of each type of media as described above, respectively. The culture plates were incubated at $30^{\circ} \mathrm{C}$ for 72 hours. Triplicate tests for the microbial culture were conducted using the sludge.

\subsection{Analytical Methods}

\subsubsection{Trace Elemental Contents}

The sludge samples were analyzed for trace elements by inductively coupled plasma (ICP). The instrument used was a Perkin Elmer Optima 3200 RL. The samples were digested in nitric acid at approximately $120^{\circ} \mathrm{C}$ in digested tubes and then dried before the ICP analysis. Sample size was $0.25 \mathrm{~g}$ after drying and grinding.

\subsubsection{Characterization of Organic Materials by Py-GC/MS and TGA}

Organic matter in the sludge was characterized using pyrolysis-GC/MS (Py-GC/MS) and thermogravimetric analysis (TGA).

Py-GC/MS was carried out using a CDS pyroprobe 5000 series with an Aglient GC-MS (5975B inert XL MSD). Samples were loaded into a quartz tube and kept the oven $\left(210^{\circ} \mathrm{C}\right)$ to ensure adequate removal of oxygen prior to pyrolysis. Samples were pyrolyzed by being heated to $500^{\circ} \mathrm{C}$, and the resulting pyrolysis vapors were separated by a (5\% phenyl)-methylpolysiloxane nonpolar column. The gas flow rate was $1 \mathrm{ml} / \mathrm{min}$ and helium was the carrier gas. The gas was then sent into a mass spectrometer (Aglient Technologies 5975B Inert $\mathrm{XL}$ MSD). The mass spectrometer conditions were transfer line $150^{\circ} \mathrm{C}$, ion source $230^{\circ} \mathrm{C}$, and electron energy $70 \mathrm{eV}$. The mass spectra of predominant peaks were then compared to a mass spectra library to determine the compound in a given peak.

TGA analysis was conducted using a Mettler-Toledo TGA/SDTA851. Approximately 5 - $10 \mathrm{mg}$ of samples were loaded into an alumina pan, and vaporized in the temperature range of $25^{\circ} \mathrm{C}-600^{\circ} \mathrm{C}$ at a rate of $10^{\circ} \mathrm{C} / \mathrm{min}$. The samples were run under nitrogen atmosphere at a flow rate of $20 \mathrm{ml} / \mathrm{min}$.

\subsubsection{Determination of Water Content by Karl-Fisher (K-F) Titration}

The sludge was a heterogeneous system; including organic matter and inorganic material (see "Results and Discussion" Section). Water content in the wet sludge was determined using the K-F titration method with a Titroline KF Titrator from Schott Instruments $\mathrm{GmbH}$.
Before the titration, the wet sludge samples were dispersed well in organic solvents in order to determine water content in solvents. Several solvents, such as methanol, ethanol, hexane, toluene, and pyridine, were tested for the dispersion; only pyridine dispersed the sludge well in the solvents tested. Wet sludge was dispersed in pyridine at final concentration of $2.7 \%(\mathrm{w} / \mathrm{v})$. The water content in the wet sludge was calculated by the content of sludge in solvents and K-F titration.

\subsubsection{Ion Chromatography (IC) Analysis}

An aqueous sample collected in the purifier of the Tillikum appeared to be highly viscous. It was hypothesized that bacteria in the sludge produced viscous materials, such as polysaccharides, that were dissolved into water. In order to test this hypothesis, IC analysis was used to identify monosaccharides in the digest of the aqueous sample.

Sample preparation for IC analysis has been previously described [8]. Samples were hydrolyzed to obtain monosaccharides using acid $\left(1.0 \mathrm{~mol} / \mathrm{L}\right.$ of $\left.\mathrm{H}_{2} \mathrm{SO}_{4}\right)$ at $100^{\circ} \mathrm{C}$ for 2 hours, and then diluted to a certain concentration. Five sugars, arabinose, galatose, glucose, xylose, and fructose, were used as standard samples. Prior to analysis, all samples including standard sugar samples were filtered through $0.25-\mu \mathrm{m}$-pore-size polycarbonate membranes (Nuclepore Corporation, Pleasanton, California).

All sugar analyses were carried out using a Dionex ICS-3000 reagent free dual ion chromatography (IC) system (Sunnyvale, California), which comprised a DP dual gradient pump module, an EG dual eluent generator (with one $\mathrm{KOH}$ reservoir cartridge in use for this work) and a DC detector/chromatography module with three programmable high-pressure six-port injector valves. Briefly, the mobile phase, at a flow rate of $1.0 \mathrm{ml} / \mathrm{min}$, consisted of ultrapure water $(0.015 \mu \mathrm{S} / \mathrm{cm}$; eluent A) and $250 \mathrm{mM} \mathrm{NaOH}$ (eluent B), with the following gradient: 0.0 min: $87 \%$ A, $13 \%$ B; 20.0 min: $87 \%$ A, $13 \%$ B; 40.0 min: $15 \%$ A, $85 \%$ B; $41.0 \mathrm{~min}: 100 \%$ B; 49.0 min: $100 \%$ B; 50.0 min: $87 \%$ A, $13 \% \mathrm{~B}$; and $65.0 \mathrm{~min}: 87 \% \mathrm{~A}, 13 \%$ B. Due to the matrix interference, quantification was carried out with standard addition.

\section{Results and Discussion}

\subsection{Sludge Formation in the Purifier of the Tillikum}

Excessive sludge formation occurred on the purifier walls when running canola-based B5. The sludge material was smooth, greasy and slightly grainy. Figure 1(a) shows the buildup of sludge on the purifier inner walls, and Figure 1(b) a typical microscopic image of a sludge sample. Microdomains, ranging from 30 to $150 \mu \mathrm{m}$, were 


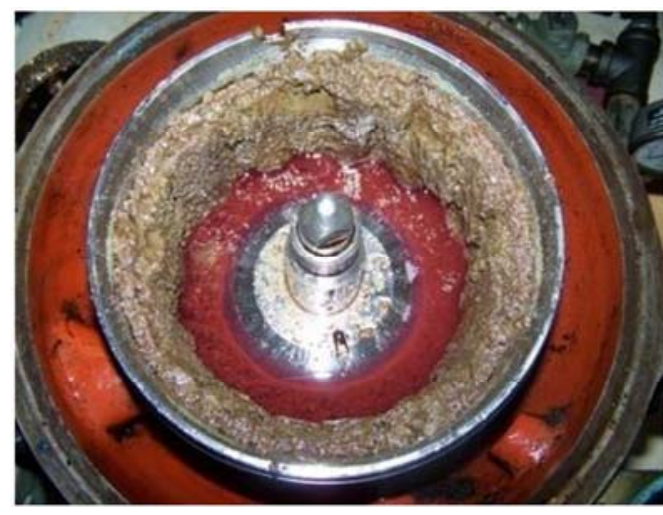

(a)

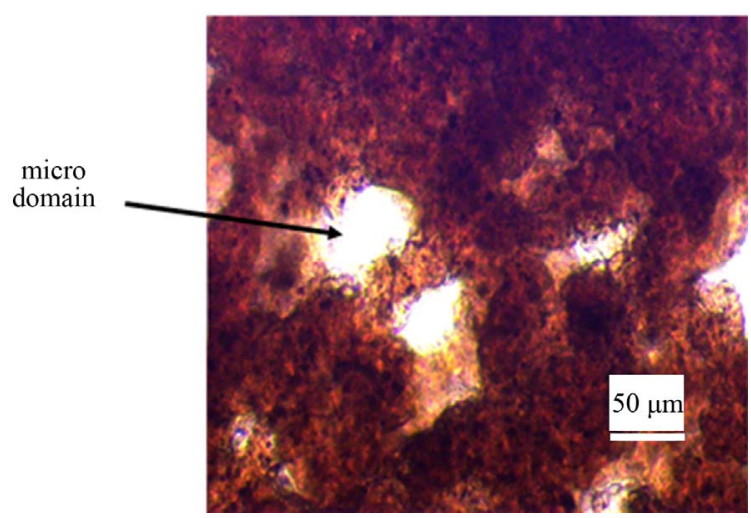

(b)

Figure 1. A representative sludge sample from the vessel using B5. (a) Sludge buildup on the purifier walls; (b) Microscopic image of the sludge (scale bar of $50 \mu \mathrm{m}$ ).

visible in this sample. Active microbes were found in the microdomains (see "Bacterial Role and Sludge Formation" Section below).

\subsection{Sludge Characterization}

\subsubsection{Contents of Ash and Metals}

The sludge samples from the vessel Tillikum contained $11 \%-14 \%(\mathrm{w} / \mathrm{w})$ ash by drying method, as shown in Table 2. The low ash content $(<15 \% \mathrm{w} / \mathrm{w})$ suggests that the major component did not come from insoluble inorganic material. But the remaining $86 \%-89 \%$ of sludge components consisted of water and organic matter. Some of this organic matter likely originated from the diesel and biodiesel.

Table 3 shows the trace elements in two sludge samples collected on different days. Unexpectedly high lev-

Table 2. Ash analysis of sludge samples.

\begin{tabular}{cccc}
\hline Sample & Vessel & Location & Ash (\% w/w) \\
\hline Sample \#1 & Tillikum & Purifier & 11 \\
Sample \#2 & Tillikum & Purifier & 14 \\
\hline
\end{tabular}

Table 3. Trace element contents in the sludge samples.

\begin{tabular}{lcc}
\hline \multicolumn{1}{c}{ Elements (mg/liter) } & Sample \#1 & Sample \#2 \\
\hline Arsenic & $<38$ & $<38$ \\
Barium & 26 & 24 \\
Beryllium & $<0.38$ & $<0.38$ \\
Calcium & 30000 & 21000 \\
Cadmium & $<1.5$ & $<1.5$ \\
Cobalt & $<1.5$ & $<1.5$ \\
Chromium & 28 & 37 \\
Copper & 92 & 50 \\
Iron & 1600 & 2400 \\
Potassium & 89 & 70 \\
Magnesium & 1500 & 1600 \\
Manganese & 41 & 33 \\
Molybdenum & 160 & 80 \\
Sodium & 4400 & 6000 \\
Nickel & 7 & 6.9 \\
Phosphorus & 4400 & 4100 \\
Lead & 34 & 18 \\
Sulfur & 5000 & 4500 \\
Vanadium & 4.1 & 5.8 \\
Zinc & 230 & 140 \\
\hline
\end{tabular}

els of calcium, iron, sodium, and sulfur were found. Since the fuel was stored in steel tanks, the source of the iron might be rusty tank walls, but the sources of the other metals were unknown. The sulfur content of the sludge was high for both samples, even though the vessel was using ULSD, which has sulfur content below $15 \mathrm{mg} / \mathrm{L}$. It should be noted that analysis was performed on sludge that built up in the purifier, but not on the fuel itself. Sulfur from the fuel may have accumulated in the sludge, or sulfur-containing materials may have been picked up from the hull of the vessel, which may contain decades-old deposits.

\subsubsection{Organic Matter in the Sludge}

Figure 2(a) shows the Py-GC/MS chromatograph of the sludge sample. The highest peak was at $31.5 \mathrm{~min}$ (Figure 2(a)). Figure 2(b) suggests that the MS pattern of this peak is consistent with 8-octadecenoic acid methyl ester (ODAME, $\mathrm{C}_{19} \mathrm{H}_{36} \mathrm{O}_{2}$ ), based on the library of standard chemicals. Thus, ODAME is one of the sludge components which could come from biodiesel based on its chemical structure.

Thermogravimetric analysis (TGA) was used to study the thermal decomposition and thermal properties of organic matter from sludge [9]. Dantas et al. investigated the thermal behavior of corn oil-based biodiesel by reacting with methanol and ethanol [10]. They reported that corn oil was thermally stable up to $336^{\circ} \mathrm{C}$, methyl biodiesel up to $145^{\circ} \mathrm{C}$, and ethyl biodiesel up to $169^{\circ} \mathrm{C}$ in nitrogen atmosphere.

TGA was also used to characterize the organic material in sludge in this study. Figure $\mathbf{3}$ shows a derivative 


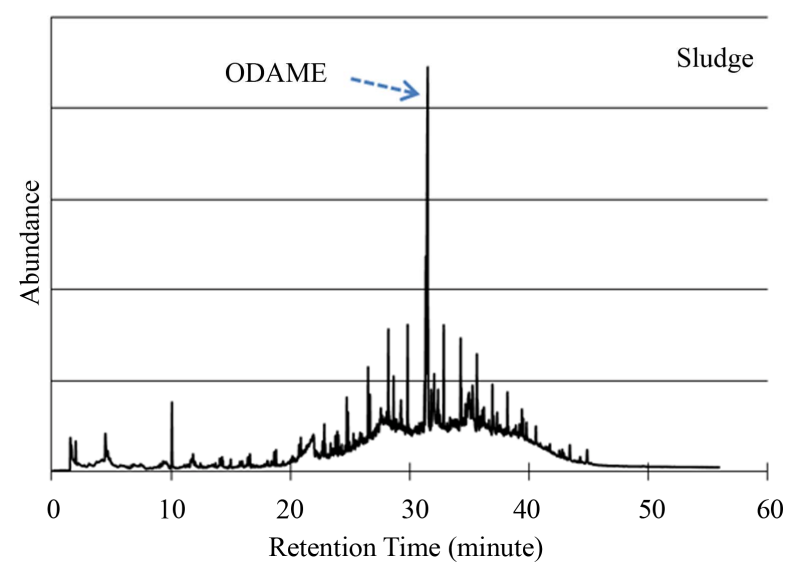

(a)

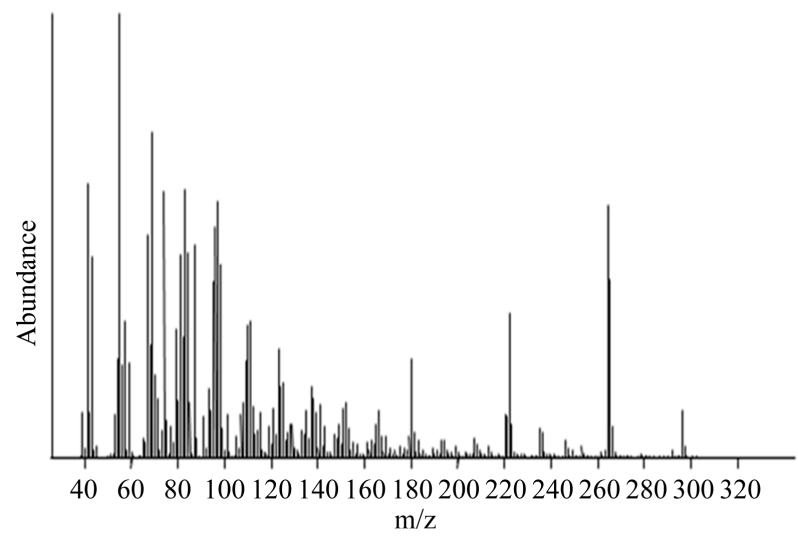

(b)

Figure 2. (a) Py-GC/MS chromatograph of the sludge sample; (b) MS pattern of 8-octadecenoic acid methyl ester (31.5 min).

thermogravimetric (DTG) curve converted from the TGA. DTG presents the rate of weight change of the samples versus the temperature change. There are two

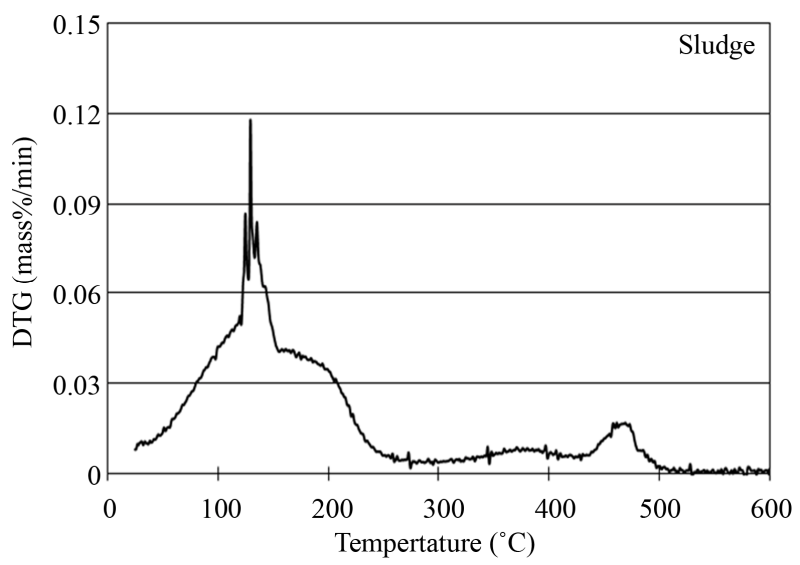

Figure 3. Derivative thermogravimetric (DTG) curve of the sludge sample. distinctive peaks apparent in Figure 3, suggesting that the sludge consists of two major fractions with different properties. The fraction within the temperature range of $430-490^{\circ} \mathrm{C}$ could be heavy components that might not come from diesel and biodiesel that could not get such high temperature [9]. However, the quantity of this fraction was small, about $6 \%$ of the sludge. A large fraction of the sludge evaporated at temperatures below $250^{\circ} \mathrm{C}$, suggesting light components or compounds with low molecular weight, including water. It is interesting that three sub-peaks at 125,130 , and $136^{\circ} \mathrm{C}$ were present. It is not clear what specific compounds account for these sub-peaks.

\subsubsection{Water Content}

Unlike the B5 fuel blend, which has low water content $(<300 \mathrm{mg} / \mathrm{L})$ [11], B5 sludge contains high levels of water, which may facilitate microbial growth (see" Bacterial Role in Sludge Formation" Section). Table 4 presents the water contents of wet sludge samples using pyridine as the K-F solvent. The solvent pyridine is miscible with water; leading to that water in the sludge could dissolve completely in the pyridine. The water content of $17.2 \% \mathrm{w} / \mathrm{w}$ ) was found, suggesting that water is one of fractions in the sludge sample.

\subsection{Bacterial Role in Sludge Formation}

\subsubsection{Observation of Bacteria Presence in the Sludge under Microscopy}

Active microbes in the sludge samples were first observed under a microscope. A great number of active bacteria, both round and rod-shaped, were found in the microdomains (Figure 4). The microbes tend to live in the microdomains, which could be water-rich. It appeared that there were several bacterial species present in the samples, but no yeasts or other fungi were observed.

Table 4. Water content in the wet sludge.

\begin{tabular}{|c|c|}
\hline Dispersed Solvent & $\mathrm{H}_{2} \mathrm{O}$ in wet sludge 0 \\
\hline Pyridine & $17.2 \pm 2.2$ \\
\hline & \\
\hline & \\
\hline & \\
\hline & 38 \\
\hline & i) \\
\hline 1,8, & 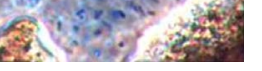 \\
\hline
\end{tabular}

Figure 4. Image of microbes in the sludge sample (scale bar of $10 \mathrm{\mu m})$. 
It is not uncommon for microorganisms to grow in hydrocarbon fuels. For example, Lutz et al. (2006) reported that bacteria commonly present in natural environments could aerobically biodegrade palm methyl or ethyl biodiesel [12]. Biodegradation of rapeseed oil methyl ester (RME) by microorganisms has also been observed [13]. Biodiesel could be more favored carbons source than diesel fuel to some microbes [14]. These reports further confirm our findings that active microbes are present in the biodiesel fuel.

Culture of sludge microbes yielded large quantities of bacteria on each of the four types of media tested. However, either fungal or yeast colonies were not found, even on the appropriate media (PDA for fungal and MEA for yeast). Therefore, it was suggested that bacteria were the dominant microbes in the sludge samples studied. The bacteria counts in the sludge from three types of culture, including aerobic and/or anaerobic conditions, were about $10^{7}$ to $10^{8} \mathrm{CFU} / \mathrm{mg}$ (colony-forming unit) sludge by plate counting. Therefore, the bacteria grew well in both anaerobic and aerobic conditions, without a significant difference.

It should be noted that multiple strains of bacteria were present in the sludge. In our previous study, isolation of bacteria was conducted from the sludge samples. Three bacterial strains as predominant growing bacteria were isolated, and further identified as Klebsiella oxytoca, Klebsiella nov. sp., and Staphylococcus epidermidis using molecular biological method as well morphological, biochemical, physiological properties [7].

Microbe origin is an interesting question. The fuel samples of B100 collected were analyzed using ASTM methods. They all met the ASTM standard specification, indicating good quality of fuel used. The biodiesel fuel blends and the sludge samples were tested using microbial kits. The fuel blends were shown to be microbial negative results while the sludge samples were positive, which further confirmed active microbes present in the sludge. Thus the results suggested that the biodiesel and fuel blends were not sources of microbial contamination. Marine environments (such as water, air) could be related with the contamination. For example, the high humidity appears to promote microbial growth. Further investigation is required to clarify this question about the microbial origin.

\subsubsection{IC Analysis of Viscous Material in the Aqueous Solution}

High viscosity in the aqueous solution was observed in the sludge samples from the purifier. It is speculated that microbes produced polysaccharides, which contributed to the high viscosity in the solution. Significant amounts of exopolysaccharides were produced by the isolated Klebsiella oxytoca using the PCA medium (Type 1 in
Table 1) [7]. In order to confirm this speculation in the sludge, the IC measurement was also used in the sludge samples to determine monosaccharide presence. Table 5 lists the monosaccharide presence of the hydrolyzed aqueous solution from the sludge sample. Galactose and glucose were found in this sample, while significant amount of xylose and fructose were not detected. Monosaccharides are probably breakdown products of polysaccharides typically produced by the isolated bacteria. So the monosaccharide composition is associated to the polysaccharides which are unclear. Relationship between bacteria and polysaccharides needs further investigation.

Extracellular polymeric substances (EPSs), such as polysaccharides produced by bacteria, represent a class of polymeric materials with a wide variety of potentially useful applications $[15,16]$. Polysaccharides of high molecular weight, such as xanthan gum, a widely used food additive, make aqueous solutions viscous [17]. It is therefore likely that polysaccharides produced by bacteria resulted in the high viscosity of the aqueous solution.

\subsubsection{Corrective Action in the Pilot Test of the Tillikum}

As discussed above, active bacteria were present in the sludge samples from the purifier, and microbial contamination occurred in the pilot tests of the Tillikum. To prevent bacterial growth, a commercial biocide (Biobor JF) was added to the fuel at dose of one gallon of the biocide per 10000 gallons of fuel. The excess sludge problem disappeared after this biocide application. The Tillikum was then shifted to canola-based B10, and later to B20, for an additional four months. The Tillikum ran biodiesel blends under the same conditions that would have been used for regular diesel, without any problems. These results provide a strong indication that bacteria played an important role in sludge formation in the Tillikum purifier. Biocide application is therefore highly recommended for marine conditions to prevent excess sludge formation and filter clogging. The presence of the biocide does not have a negative influence on engine operation. Biocide products are typically pesticides, which inhibit the growth of microbes over long periods of time in very low concentrations. Further investigation requires understanding the interaction between biocide and specific microbial species. This information would be useful to screen better biocides in terms of higher

Table 5. Monosaccharide composition analysis in the aqueous solution by ion chromatography.

\begin{tabular}{lccccc}
\hline Sample & Arabinose & Galactose & Glucose & Xylose & Fructose \\
\hline Sludge & - & + & + & - & - \\
\hline $\begin{array}{l}\text { Note: 1: The samples were hydrolyzed with } 1.0 \\
\text { diluted } 1\end{array}$ & 000 -fold before sampling. 2 : "-" indicates no sugar $\mathrm{H}_{2} \mathrm{SO}_{4}$ and then \\
"+" indicates sugar was detected.
\end{tabular}


performance and lower cost.

\section{Conclusions}

Excess sludge was formed in the purifier of the Tillikum when the vessel was fueled by canola-based B5. The sludge sample contained metal (11\% - 14\% ash), water $(\sim 17 \%)$, major fraction of organic materials, and bacteria. Active bacteria present in the sludge grew in culture media under both anaerobic and aerobic conditions. It is suggested that the bacteria played a key role in sludge formation, as shown by the absence of sludge problems after addition of biocide to the fuel for the remainder of the study period.

\section{Acknowledgements}

This work was supported by the Department of Energy under Award Number (DE-FG36-06GO86032) through a contract (200700001) between the Puget Sound Clean Air Agency (PSCAA) and Washington State University (WSU). The authors are thankful to Imperium Renewables Inc (IRI). for providing biodiesel fuel, Washington State Ferries (WSF) for the pilot tests and samples collecting, the Analytical Science Laboratory at the University of Idaho (UI) for ICP analysis, and the Franceschi Microscopy and Imaging Center at WSU for microscope images. The authors also gratefully acknowledge the individuals for their great assistance in the project: $\mathrm{Mr}$. Tom Hudson from the PSCAA, Mr. Paul Brodeur and Mr. Scott Calhoun from WSF, Mr. John Herkes of the UI, Mr. Todd Ellis from IRI., Mr. Jake Millan, Mr. David W. Larsen, Mr. Paul S. Smith, and Ms. Lisa Renehan from the Glosten Associates, Mr. Shi-Shen Liao and Ms. Joan Million from WSU.

\section{References}

[1] U. S. Department of Energy, "Biodiesel Handling and Use Guideline," 2nd Edition, 2006. http://www.osti.gov/bridge

[2] R. O. Dunn, "Cold Weather Properties and Performance of Biodiesel," In: G. Knothe, J. Krahl and J. Van Gerpen Eds., The Biodiesel Handbook, AOCS Press, Urbana, 2005, pp. 83-121. doi:10.1201/9781439822357.ch6.3

[3] D. S. Shrestha, J. Van Gerpen and J. Thompson, "Effectiveness of Cold Flow Additives on Various Biodiesel, Diesel and their Blends," Transactions of ASABE, Vol. 51, No. 14, 2008, pp. 1365-1370.

[4] H. Tang, C. Rhet and C. De Guzman, "Formation of Insolubles in Palm Oil-, Yellow Grease-, and Soybean Oil-Based Biodiesel Blends after Cold Soaking at $4^{\circ} \mathrm{C}$," Journal of the American Oil Chemists' Society, Vol. 85, No. 12, 2008, pp. 1131-1182.

[5] H. Tang, S. O. Salley and K. Y. S. Ng, "Fuel Properties and Precipitate Formation at Low Temperature in Soy-,
Cottonseed-, and Poultry Fat-Based Biodiesel Blends," Fuel, Vol. 87, No. 13-14, 2008, pp. 3006-3017. doi:10.1016/j.fuel.2008.04.030

[6] S. Chen, "Report of Findings from 2004 WSF Biodiesel Pilot Test," Pullman, 2007.

http://www.wsdot.wa.gov/NR/rdonlyres/84094DDC-194 E-4FB3-8D28-6916F6E5E058/0/B_Appendix_2004_Pilo t_Test_15April09.pdf

[7] Y. Chao, N. Liu, T. Zhang and S. Chen, "Isolation and Characterization of Bacteria from Engine Sludge Generated from Biodiesel-Diesel Blends," Fuel, Vol. 89, No. 11, 2010, pp. 3358-3364. doi:10.1016/j.fuel.2010.05.041

[8] S. Apirattananusorn, S. Tongta, S. W. Cui and Q. Wang, "Chemical, Molecular, and Structural Characterization of Alkali Extractable Nonstarch Polysaccharides from Job's Tears," Journal of Agricultural and Food Chemistry, Vol. 56, No. 18, 2008, pp. 8549-8557. doi:10.1021/jf801231y

[9] J. Dweck, and C. M. S. Sampaio, "Analysis of the Thermal Decomposition of Commercial Vegetable Oils in Air by Simultaneous TG/DTA," Journal of Thermal Analysis and Calorimetry, Vol. 75, No. 2, 2004, pp. 385-391. doi:10.1023/B:JTAN.0000027124.96546.0f

[10] M. B. Dantas, M. M. Conceio, Jr., V. J. Fernandes, N. A. Santos, R. Rosenhaim, A. L. B. Marques, I. M. G. Santos and A. G. Souza, "Thermal and Kinetic Study of Corn Biodiesel Obtained by the Methanol and Ethanol Routes," Journal of Thermal Analysis and Calorimetry, Vol. 87, No. 3, 2007, pp. 835-839. doi:10.1007/s10973-006-7780-2

[11] B. He, J. Thompson, D. Routt and J. Van Gerpen, "Moisture Absorption in Biodiesel and Its Petro-Diesel Blends," Applied Engineering in Agriculture, Vol. 23, No. 1, 2007, pp. 71-76.

[12] J. Lutz, M. Chavarra, M. L. Arias and J. F. Mata-Segreda, "Microbial Degradation of Palm (Elaeis guineensis) Biodiesel," Revista de Biologia Tropical, Vol. 54, No. 1, 2006, pp. 59-63.

[13] T. Schleicher, R. Werkmerster, W. Russ and R. Meyer-Pittoff, "Microbiological Stability of Biodiesel-Diesel Mixtures," Bioresource Technology, Vol. 100, No. 2, 2009, pp. 724-730. doi:10.1016/j.biortech.2008.07.029

[14] M. Owsianiak, L. Chrzanowski, A. Szulc, J. Stainewski, A. Olszanowski, A. K. Olejnik-Schidt and H. J. Heipieper, "Biodegradation of Disel/Biodiesel Blends by a Consortium of Hydrocarbon Degraders: Effect of the Type of Blend and the Addition of Biosurfactants," Bioresource Technology, Vol. 100, No. 3, 2009, pp. 1497-1500. doi:10.1016/j.biortech.2008.08.028

[15] R. De Philippis, R., C. Sili, R. Paperi and M. Vincenzini, "Exopolysaccharide-Producing Cyanobacteria and Their Possible Exploitation: A Review," Journal of Applied Physiology, Vol. 13, 2001, pp. 293-299.

[16] S. Kumar, K. Mody and B. Jha, "Bacterial Exopolysaccharides-A Perception," Journal of Basic Microbiology, Vol. 47, 2007, pp. 103-117. doi:10.1002/jobm.200610203

[17] S. Rosalam and R. England, "Review of Xanthan Gum Production from Unmodified Starches by Xanthomonas comprestris sp.," Enzyme and Microbial Technology, Vol. 39, No. 2, 2006, pp. 197-207. doi:10.1016/j.enzmictec.2005.10.019 